Ю. М. Кузьмінська, директор Вищої школи управління e-mail: jkuzminskaya@gmail.com

Вищий навчальний заклад «Міжрегіональна Академія управління персоналом» вул. Фрометівська, 2, м. Київ, 03039, Україна

\title{
ПРАКТИЧНЕ ЗАСТОСУВАННЯ МОДЕЛЕЙ ТА МЕТОДІВ УПРАВЛІННЯ КРЕАТИВНІСТЮ І РИЗИКАМИ КОМАНД ОСВІТНІХ ПРОЕКТІВ У СФЕРІ ПІДВИЩЕННЯ КВАЛІФІКАЦІї
}

Сучасне життя потребує швидкого та постійного розвитку: професійні знання, здобуті людиною, вже за кілька років стають застарілими та потребують оновлення. У професійній діяльності від прачівників постійно вимагається мобільність $і$ здатність до змін. Нерівномірність підготовки кадрів, перевиробництво кадрів одного профілю йде на шкоду іншим професіям, актуалізує потребу в пожиттєвому навчанні. Тому якраз в управлінні освітніми проектами у сфері підвищення кваліфікаиії, яка є складовою навчання впродовж життя і плащдармом для вирощування сучасних кадрів, добре себе зарекомендував саме проектний менеджмент.

Зазвичай команда освітнього проекту складається з креативних осіб, підібраних з-поміж внутрішніх прачівників навчального закладу. Управління такими командами пов'язане з певними ризиками персоналу, що може в подальшому шкодити успішному завершенню освітнього проекту. Робота з командами, члени яких мають високий креативний потенціал, потребує додаткових і дієвих інструментів та методів управління.

Статтю присвячено аспектам практичного застосування розроблених автором моделей та методів управління креативністю і ризиками команд освітніх проектів у сфері підвищення кваліфікації. На прикладі освітнього проекту розробки та запуску програм підвищення кваліфікації за ваучерами в приватному закладі вищої освіти було виконано оцінювання креативності членів команд освітнього проекту за допомогою соиіометричного методу перехресного оцінювання, й експертним методом визначено ризики персоналу, що найбільше впливають на результат проекту. За допомогою методу управління трудовими ресурсами освітніх проектів з урахуванням їх креативності та ризиків було визначено ступінь довіри до кожного члена команди проекту для подальшого планування проектним менеджером трудових ресурсів на критичному шляху освітнього проекту.

Ключові слова: освітній проект, сфера підвищення кваліфікації, команда проекту, управління, креативність, ризики, ступінь довіри.

Постановка проблеми. В сучасній освіті вищі навчальні заклади все частіше та частіше починають співпрацювати з бізнесом та державою, брати участь у спільних проектах щодо підготовки фахових кадрів для потреб ринку праці, починаючи впроваджувати в свою діяльність проектний підхід.

Освіта впродовж життя є загальновизнаною необхідністю, яку Європейський Союз розглядає як важливий елемент соціальної моделі сучасного суспільства. Головним завданням навчання впродовж життя $є$ навчання дорослого населення або безперервне підвищення кваліфікації дорослих громадян для всебічного задоволення їх освітніх потреб і забезпечення їхньої конкурентоспроможності на ринку праці.

Під підвищенням кваліфікації розуміють підвищення рівня готовності особи до виконання піi професійних завдань та обов'язків або набуття особою здатності виконувати додаткові завдання та обов'язки шляхом набуття нових знань і вмінь у межах професійної діяльності або галузі знань [1].

Освітній проект у сфері підвищення кваліфікації - це проект, який реалізується в галузі вищої освіти, результатом якого $\epsilon$ набуті особою нові та/або вдосконалені раніше набуті компетентності у межах професійної діяльності або галузі знань, і щодо якого чітко визначено мету та базові обмеження: зміст, час, вартість, якість, ризики, ресурси.

Метою підвищення кваліфікації $є$ зростання рівня знань та умінь усіх громадян за невеликий термін часу протягом усього життя за рахунок навчання за окремими темами, розділами, модулями чи дисциплінами на курсах підвищення кваліфікації, професій- 
них курсах, курсах цільового призначення, дистанційних курсах, семінарах, тренінгах, майстер-класах, «воркшопах», «хакатонах» тощо. Всі ці освітні проекти, основним фактором впливу на успішний кінцевий результат яких є людський фактор, є типовими.

Останнім часом до управління командами освітніх проектів активно застосовуються креативні підходи. Інтерес до креативного управління або творчого підходу до вирішення завдань у рамках проекту обумовлений популяризацією використання високої оригінальності й нестандартності мислення для вирішення ключових проблем проекту.

Застосування до управління командами освітніх проектів у сфері підвищення кваліфікації креативних технологій є необхідною, але ризикованою справою, адже при управлінні такою командою неможливо буде спрогнозувати негативні результати та уникнути їх.

Аналіз останніх досліджень. Виходячи зі сформульованої вище проблеми, автором виконано аналіз робіт, присвячених застосуванню методології управління проектами в освітній сфері. Аналіз показав, що управління проектами і програмами в освітній галузі $\epsilon$ вже досить дослідженим явищем. Так, багато робіт було присвячено застосуванню інструментів проектного менеджменту та проектноорієнтованому управлінню у вищих начальних закладах [2-5], але проблематика управління креативними командами освітніх проектів та їх ризиками саме у сфері підвищення кваліфікації була недостатньо вивченою, тому досліджувалася автором протягом тривалого часу.

Так, в результаті проведених досліджень автором у роботах $[6,7,8]$ було побудовано моделі креативного управління освітніми проектами у сфері підвищення кваліфікації: концептуальну, математичну та когнітивну, а в роботі [9] було виконано оцінювання креативності в освітніх проектах у сфері підвищення кваліфікації за допомогою методу перехресної соціометричної оцінки. В свою чергу, в роботі [6] також було розроблено метод управління трудовими ресурсами освітніх проектів 3 урахуванням їх креативності та ризиків.

Кінцевим результатом цієї роботи стало застосування на практиці розроблених автором моделей і методів.

Метою статті $є$ практичне застосування розроблених автором моделей і методів управ- ління креативністю та ризиками команд освітніх проектів у сфері підвищення кваліфікації на прикладі реального проекту розробки та запуску програм підвищення кваліфікації за ваучерами в приватному закладі вищої освіти.

Виклад основного матеріалу. Ваучерна система становить альтернативу прямій закупівлі освітніх послуг через державну службу зайнятості та широко застосовується вже багато років у країнах Свропи та країнах, що розвиваються.

Освітні проекти підвищення кваліфікації за ваучерами на сьогодні $є$ досить важливими й актуальними як для самих вищих навчальних закладів, так і для держави в цілому.

Запровадження в своїй діяльності навчання за програмами підвищення кваліфікації за ваучерами для осіб старшого віку, в першу чергу, є доцільним саме для приватних закладів вищої освіти. В результаті, така спеціальна державна програма дасть можливість цим особам підвищити свою конкурентоспроможність на ринку праці, а закладу вищої освіти допоможе популяризувати свої освітні програми та підвищити власний імідж серед інших закладів освіти.

За два останні десятиліття перед Україною постала проблема працевлаштування осіб, старших 45 років. Незважаючи на те, що працівники такого віку мають певні професійні навички та досвід, вони зовсім не користуються «попитом» на ринку праці, як виявилося, через найуразливішу сторону конкурентоспроможності населення старшого віку освітньо-кваліфікаційний рівень.

В Україні люди, старші 45 років, здобували освіту ще за радянських часів, тобто за зовсім інших економічних, політичних та соціальних умов. Професійна спрямованість і зміст їхньӧ освіти також були орієнтовані зовсім на іншу структуру економіки, іншу організацію праці та інші технології. Через неактуальні дипломи формальна наявність вищої освіти далеко не завжди дає можливість влаштуватися на робочі місця відповідної кваліфікації [10]. Тому такі фахівці особливо потребують підвищення кваліфікації та оновлення отриманих раніше знань.

Сьогодні роботодавці під час підбору персоналу ставляться досить упереджено до осіб старшого віку та неохоче беруть їх на роботу, вважаючи «перенавчання» проблемним і невигідним. Керівництво підприємств, 
установ та організацій не готове вкладати в освіту та професійний розвиток працівників, яким залишилося 10-15 років до досягнення пенсійного віку. Як наслідок, статистика показує, що частка безробітних у цій віковій групі вдвічі вища, ніж серед молодших громадян працездатного віку [11].

Одним із інструментів практичного втілення концепції освіти впродовж життя, який дає можливість особам старшого віку бути конкурентоспроможними на ринку праці, $€$ ваучер на професійну підготовку, спеціальна програма видачі якого почала застосовуватися в Україні в рамках активної політики ринку праці з 2013 р.

Ваучер - це документ встановленого зразка, що дає особі одноразове право на перепідготовку, підготовку на наступному освітньо-кваліфікаційному рівні, спеціалізацію чи підвищення кваліфікації у навчальних закладах чи у роботодавця, тобто документ, який забезпечує право громадянина на навчання коштом держави [12].

Програма передбачає не тільки навчання тих, хто залишився без роботи, але й можливість підвищення конкурентних пе- реваг для співробітників за рахунок держави. Для цього необхідно мати бажання навчатися і відповідати деяким критеріям: бути старшим 45 років (до настання пенсійного віку), мати страховий стаж, не менший ніж 15 років, надати до Центру зайнятості підтверджуючі документи [13].

Отримавши такий ваучер, громадянин може пройти підвищення кваліфікації за професіями та спеціальностями відповідно до затвердженого законодавством переліку [14], а також самостійно вибрати форму і місце навчання.

Протягом 2017-2018 рр. на базі одного 3 приватних закладів вищої освіти було успішно реалізовано освітній проект з розробки та запуску програм підвищення кваліфікації за ваучерами.

Навчальний заклад запропонував розробити для осіб старшого віку (старших 45 років) 10 програм підвищення кваліфікації за п'ятьма спеціальностями відповідно до своєї ліцензії та організувати навчання на курсах підвищення кваліфікації за ваучерами на базі одного зі своїх підрозділів - Вищої школи управління (табл. 1).

Таблиця 1 - Програми підвищення кваліфікації для осіб старшого віку за ваучерами

\begin{tabular}{|c|c|c|}
\hline № & Спеціальність & Програма підвищення кваліфікації \\
\hline \multirow[t]{5}{*}{1} & \multirow{5}{*}{$\begin{array}{c}\text { Інженерія } \\
\text { програмного } \\
\text { забезпечення }\end{array}$} & Фахівець з розроблення комп'ютерних програм (Java SE) \\
\hline & & Програмування web-додатків мовою Python \\
\hline & & Web-програмування \\
\hline & & Фахівець з тестування програмного забезпечення (QA Testing) \\
\hline & & Інформаційне забезпечення IT-проектів \\
\hline 2 & $\begin{array}{c}\text { Комп'ютерна } \\
\text { інженерія }\end{array}$ & $\begin{array}{l}\text { Комп'ютерна грамотність: використання персонального } \\
\text { комп’ютера для роботи на підприємствах, в організаціях } \\
\text { (установах) }\end{array}$ \\
\hline 3 & Менеджмент & Менеджер (управитель) житлового будинку (групи будинків) \\
\hline \multirow[t]{2}{*}{4} & \multirow[t]{2}{*}{ Психологія } & Практична психологія \\
\hline & & Медична психологія \\
\hline 5 & Соціальна робота & Соціальний працівник \\
\hline
\end{tabular}

Керівником проекту було призначено директора Вищої школи управління, який відповідав за організацію та проведення підвищення кваліфікації фахівців у цьому приватному закладі освіти.

3-поміж співробітників навчального закладу (з відповідних підрозділів) було сформовано команду освітнього проекту у сфері підвищення кваліфікації, до якої входили: керівник проекту, асистент керівника проекту, офіс-менеджер, бухгалтер, юрист, менеджер зі зв'язків з громадськістю та реклами і група викладачів (дев'ять осіб).

У ході роботи 3 членами команди освітнього проекту було виявлено, що кожен 3 них володіє достатньо високим креативним потенціалом, що може призвести до ризику незавершеності проекту або навіть його зриву.

У такому освітньому проекті, який ще й $\epsilon$ обмеженим у строках виконання, при високій креативності членів команди проекту було вирішено зменшувати ризики таким чином, 
щоб можна було після завершення отримати успішний проект 3 мінімальними втратами.

Для визначення, кого з членів команди можна було б поставити на виконання паралельних чи критичних робіт, або робіт 3 високим пріоритетом, було використано метод управління трудовими ресурсами освітніх проектів з урахуванням їх креативності та ризику [6].

В [15] було встановлено, що до ризиків, які найчастіше виникають в освітніх проектах у сфері підвищення кваліфікації, відносяться такі ризики персоналу: організаційний ризик (R1), кадровий ризик (R2), ризик плинності кадрів (R3), ризик недостатньої кваліфікації персоналу (R4), ризик помилки (R5), ризик менеджменту (R6), методичний ризик (R7), оскільки саме ці ризики, в ході досліджень, попали в червону зону ризиків.

Відповідно до методу, в першу чергу, необхідно було оцінити виділені ризики членів команди освітнього проекту:

$$
R_{j}=\sum_{i=1}^{7} R R_{i j}, i=\overline{1,7}, j=\overline{1, k},
$$

де $i$ - порядковий номер ризику, що оцінюється, $j$ - номер члена команди освітнього проекту, $k$ - кількість членів команди освітнього проекту, $R R_{i j}$ - проранжований $i$-й ризик $j$-го члена команди проекту.

Визначені ризики найбільше пов'язані саме $з$ управлінням командою освітнього проекту, тому в процесі оцінювання ризиків було використано експертний метод. Експертиза мала індивідуальний та очний характер.

Експертом, який проводив оцінювання інших членів команди освітнього проекту, виступав керівник проекту, адже за попереднім досвідом роботи в інших проектах він вже добре знав можливості кожного 3 них. Експерту необхідно було оцінити ризики асистента керівника проекту, офісменеджера, бухгалтера, юриста і менеджера зі зв'язків з громадськістю та реклами, кожен 3 яких був поставлений на виконання різних задач. Сам експерт теж мав право голосу він оцінював свої ризики самостійно, тобто для оцінювання ризиків керівника проекту було використано метод самооцінки.

Група викладачів не брала участі в оцінюванні, тому що вони були поставлені на виконання тільки однієї задачі - розробки навчальних планів та програм підвищення кваліфікації, їх навчально-методичного забезпечення.

Для оцінювання ризиків керівнику проекту необхідно було заповнити шість відповідних анкет: на себе і на кожного члена команди освітнього проекту (табл. 2). Колонки цієї анкети відповідали номерам учасників оцінювання, а в рядках були вказані ризики кожного члена команди освітнього проекту, що необхідно оцінити: ймовірність виникнення ризику $\left(P_{1}, P_{2}, P_{3}, P_{4}, P_{5}, P_{6}\right)$ та ступінь впливу ризику на хід проекту $\left(V_{1}, V_{2}\right.$, $\left.V_{3}, V_{4}, V_{5}, V_{6}\right)$.

Ймовірність, як завжди, визначається суб' єктивно і не може бути $100 \%$ або навіть $80 \%$, оскільки така ймовірність виводить проблему 3 розряду ризиків і переводить у розряд фактів. Отже, з урахуванням цього керівник проекту оцінював значення ймовірностей $P_{j}$ від 0 до 1 (у відповідних колонках табл. 2) для кожного ризику як для кожного члена проектної команди, так і для себе.

Далі керівник проекту оцінював ступінь впливу кожного ризику на хід проекту для кожного члена команди проекту від 0 до 1 за такою шкалою (у відповідних колонках табл. 2):

$$
\begin{aligned}
& 0,0 \text { - 0,2 - дуже низький; } \\
& 0,2 \text { - 0,4 - низький; } \\
& 0,4 \text { - 0,6 - середній; } \\
& 0,1 \text { - 0,8 - високий; } \\
& 0,8 \text { - 1,0 - дуже високий. }
\end{aligned}
$$

Далі необхідно було проранжувати ризики (табл. 3), тобто визначити $R R_{i j}$ (Risk Ranking) для кожного ризику за формулою

$$
R R_{i j}=P_{i j} \times V_{i j}, \quad i=\overline{1,7}, j=\overline{1, k},
$$

де $P_{i j}-$ ймовірність виникнення $i$-го ризику, що оцінюється, $j$-го члена команди освітнього проекту; $V_{i j}$ - вплив на хід освітнього проекту $i$-го ризику, що оцінюється, $j$-го члена команди освітнього проекту.

Результати оцінювання ризиків, яке проводилося за цією схемою, наведено в табл. 2 i 3 .

Достовірність наведених результатів було підтверджено на практиці експериментальним шляхом під час реалізації проекту.

Наступним кроком було оцінювання креативності членів команди освітнього проекту у сфері підвищення кваліфікації за допомогою методу перехресної соціометричної оцінки, який використовують для вивчення внутрішньоколективних (внутрішньокомандних) зв'язків шляхом виявлення відносин між членами команди проекту. Тут цей метод було застосовано для дослідження міжособистісних відносин між членами команди проекту та у команді в цілому з метою їх поліпшення. 
Таблиця 2 - Анкета оцінювання ризиків

\begin{tabular}{|c|c|c|c|c|c|c|c|c|c|c|c|c|}
\hline \multirow{2}{*}{$\begin{array}{l}\text { Члени команди } \\
\text { проекту } \\
\text { оцинюю, щд } \\
\text { оцінся }\end{array}$} & \multicolumn{2}{|c|}{$\begin{array}{c}\text { Керівник } \\
\text { проекту }\end{array}$} & \multicolumn{2}{|c|}{$\begin{array}{c}\text { Асистент } \\
\text { керівника } \\
\text { проекту }\end{array}$} & \multicolumn{2}{|c|}{$\begin{array}{c}\text { Офіс- } \\
\text { менеджер }\end{array}$} & \multicolumn{2}{|c|}{ Бухгалтер } & \multicolumn{2}{|c|}{ Юрист } & \multicolumn{2}{|c|}{$\begin{array}{c}\text { Менеджер зі } \\
\text { зв'язків з громадсь- } \\
\text { кістю та реклами }\end{array}$} \\
\hline & $\overline{P_{1}}$ & $\overline{V_{1}}$ & $P_{2}$ & $V_{2}$ & $P_{3}$ & $V_{3}$ & $P_{4}$ & $V_{4}$ & $P_{5}$ & $V_{5}$ & $P_{6}$ & $V_{7}$ \\
\hline$R 1$ & 0,1 & 0,8 & 0,2 & 0,8 & 0,3 & 0,6 & 0,3 & 0,3 & 0,4 & 0,5 & 0,2 & 0,6 \\
\hline$R 2$ & 0,1 & 0,8 & 0,2 & 0,6 & 0,2 & 0,5 & 0,2 & 0,2 & 0,3 & 0,4 & 0,3 & 0,4 \\
\hline$R 3$ & 0,1 & 0,8 & 0,3 & 0,8 & 0,4 & 0,3 & 0,5 & 0,3 & 0,6 & 0,4 & 0,5 & 0,5 \\
\hline$R 4$ & 0,1 & 0,8 & 0,3 & 0,7 & 0,6 & 0,4 & 0,5 & 0,6 & 0,2 & 0,7 & 0,4 & 0,6 \\
\hline$R 5$ & 0,3 & 0,7 & 0,3 & 0,6 & 0,7 & 0,5 & 0,4 & 0,7 & 0,4 & 0,5 & 0,2 & 0,5 \\
\hline$R 6$ & 0,3 & 0,7 & 0,5 & 0,6 & 0,6 & 0,4 & 0,5 & 0,3 & 0,2 & 0,3 & 0,2 & 0,4 \\
\hline$R 7$ & 0,4 & 0,5 & 0,3 & 0,6 & 0,3 & 0,4 & 0,2 & 0,7 & 0,2 & 0,7 & 0,2 & 0,6 \\
\hline
\end{tabular}

Таблиця 3 - Результати оцінювання ризиків керівником проекту

\begin{tabular}{|c|c|c|c|c|c|c|}
\hline $\begin{array}{c}\text { Номер } \\
\text { параметра }\end{array}$ & $\begin{array}{c}\text { Керівник } \\
\text { проекту }\end{array}$ & $\begin{array}{c}\text { Асистент } \\
\text { керівника } \\
\text { проекту }\end{array}$ & $\begin{array}{c}\text { Офіс- } \\
\text { менеджер }\end{array}$ & Бухгалтер & Юрист & $\begin{array}{c}\text { Менеджер зі } \\
\text { зв'язків з громадсь- } \\
\text { кістю та реклами }\end{array}$ \\
\hline$R R 1$ & 0,08 & 0,16 & 0,18 & 0,09 & 0,20 & 0,12 \\
\hline$R R 2$ & 0,08 & 0,12 & 0,10 & 0,04 & 0,12 & 0,12 \\
\hline$R R 3$ & 0,08 & 0,24 & 0,12 & 0,15 & 0,24 & 0,25 \\
\hline$R R 4$ & 0,08 & 0,21 & 0,24 & 0,30 & 0,14 & 0,24 \\
\hline$R R 5$ & 0,21 & 0,18 & 0,35 & 0,28 & 0,20 & 0,10 \\
\hline$R R 6$ & 0,21 & 0,30 & 0,24 & 0,15 & 0,06 & 0,08 \\
\hline$R R 7$ & 0,20 & 0,18 & 0,12 & 0,14 & 0,14 & 0,12 \\
\hline$R_{j}$ & 0,94 & 1,39 & 1,35 & 1,15 & 1,10 & 1,03 \\
\hline
\end{tabular}

Індекс креативності кожного члена команди освітнього проекту, достовірність розрахунку якого також була підтверджена експериментальним шляхом вже в ході реалізації проекту, був розрахований за формулою

$$
K_{j}=\sum_{m=1}^{N} \frac{\sum_{j=1}^{k-1} K_{m j}}{k-1}, m=\overline{1, N}, j=\overline{1, k-1},
$$

де $j$ - номер члена команди проекту, $k$ - кількість членів команди проекту, $m$ - порядковий номер параметра креативності, $N$ - кількість параметрів креативності, $K_{m j}-$ кількість балів при оцінюванні $m$-го параметра креативності $j$-го члена команди освітнього проекту.

Процедура перехресного соціометричного опитування має низку переваг: вона проста; займає мало часу; викликає зацікавленість; легко піддається статистичній обробці; доступна для всіх членів команди освітнього проекту; дає підстави і можливість змінювати взаємовідносини в команді.

В роботах $[8,9]$ було визначено та описано 10 параметрів креативності членів команди освітнього проекту у сфері підвищення кваліфікації: рутинність $(K 1)$, консервативність $(K 2)$, прогресивність $(K 3)$, ініціативність
$(K 4)$, новизна $(K 5)$, деструктивність $(K 6)$, оптимальність $(K 7)$, інноваційність $(K 8)$, ефективність $(K 9)$, динамічність $(K 10)$, тобто в нашому випадку $N=10$.

Як об'єкти дослідження були обрані ті самі шість членів команди освітнього проекту, що й при оцінюванні ризиків, які добре знають один одного по спільній роботі: керівник проекту, асистент керівника проекту, офіс-менеджер, бухгалтер, юрист, менеджер зі зв'язків з громадськістю та реклами.

Під час оцінювання параметрів креативності кожний учасник анкетування отримав анонімну анкету (табл. 4). Колонки цих анкет відповідали номерам членів команди, а в рядках були відзначені оцінювані якості - параметри креативності.

Цього разу опитуваному необхідно було поставити оцінки іншим п'яти учасникам анкетування за такою чотирибальною шкалою (у відповідних колонках табл. 4):

4 - якість виражена сильною мірою, виявляється часто;

3 - якість виражена середньою мірою, виявляється час від часу; 
2 - якість виражена слабо, виявляється рідко або взагалі відсутня;

1 - важко відповісти.

Сам опитуваний свої параметри креативності не оцінював, адже була ймовірність того, що в його самооцінці можна буде виявити відхилення від дійсності. Тобто в цьому випадку для підвищення об’єктивності оцінки ця частина перехресного соціометричного методу не використовувалася.

Приклад анкетування параметрів креативності подано в табл. 4, де керівник проекту оцінює решту членів команди освітнього проекту у сфері підвищення кваліфікації.

Аналогічно було проведено оцінювання параметрів креативності по решті учасників анкетування.

Таблиця 4 - Зразок заповненої анкети оцінювання параметрів креативності

\begin{tabular}{|c|c|c|c|c|c|c|}
\hline $\begin{array}{c}\text { Оцінюваний } \\
\text { параметр } \\
\text { кративності }\end{array}$ & $\begin{array}{c}\text { Керівник } \\
\text { проекту }\end{array}$ & $\begin{array}{c}\text { Асистент } \\
\text { керівника } \\
\text { проекту }\end{array}$ & $\begin{array}{c}\text { Офіс- } \\
\text { менеджер }\end{array}$ & Бухгалтер & Юрист & $\begin{array}{c}\text { Менеджер зі } \\
\text { зв'язків 3 громадсь- } \\
\text { кістю та реклами }\end{array}$ \\
\hline$K 1$ & - & 3 & 3 & 3 & 1 & 1 \\
\hline$K 2$ & - & 3 & 3 & 3 & 1 & 3 \\
\hline$K 3$ & - & 1 & 2 & 3 & 3 & 4 \\
\hline$K 4$ & - & 2 & 1 & 3 & 4 & 3 \\
\hline$K 5$ & - & 2 & 1 & 4 & 3 & 2 \\
\hline$K 6$ & - & 3 & 3 & 4 & 4 & 3 \\
\hline$K 7$ & - & 1 & 2 & 2 & 2 & 1 \\
\hline$K 8$ & - & 1 & 2 & 3 & 3 & 1 \\
\hline$K 9$ & - & 1 & 3 & 1 & 1 & 3 \\
\hline$K 10$ & - & 2 & 1 & 3 & 3 & 2 \\
\hline
\end{tabular}

Далі виконувався табличний етап обробки даних, що передбачав побудову таблиці, за оцінювання (табл. 5).

Таблиця 5 - Узагальнені результати оцінювання

\begin{tabular}{|c|c|c|c|c|c|c|}
\hline $\begin{array}{c}\text { Сума всіх оцінок } \\
\text { по кожному } \\
\text { параметру } \\
\text { креативності }\end{array}$ & $\begin{array}{c}\text { Керівник } \\
\text { проекту }\end{array}$ & $\begin{array}{c}\text { Асистент } \\
\text { керівника } \\
\text { проекту }\end{array}$ & $\begin{array}{c}\text { Офіс- } \\
\text { менеджер }\end{array}$ & Бухгалтер & Юрист & $\begin{array}{c}\text { Менеджер зі } \\
\text { зв’язків } \\
\text { з громадськістю } \\
\text { та реклами }\end{array}$ \\
\hline$K_{(1,1)} \ldots K_{(1,6)}$ & 12 & 13 & 11 & 10 & 15 & 16 \\
\hline$K_{(2,1)} \ldots K_{(2,6)}$ & 12 & 11 & 11 & 13 & 19 & 10 \\
\hline$K_{(3,1) \ldots K_{(3,6)}}$ & 20 & 17 & 15 & 14 & 15 & 15 \\
\hline$K_{(4,1)} \ldots K_{(4,6)}$ & 20 & 17 & 15 & 8 & 8 & 16 \\
\hline$K_{(5,1) \ldots K_{(5,6)}}$ & 19 & 11 & 13 & 6 & 7 & 11 \\
\hline$K_{(6,1)} \ldots K_{(6,6)}$ & 9 & 9 & 10 & 10 & 12 & 9 \\
\hline$K_{(7,1)} \ldots K_{(7,6)}$ & 20 & 16 & 12 & 19 & 17 & 16 \\
\hline$K_{(8,1)} \ldots K_{(8,6)}$ & 20 & 14 & 11 & 15 & 14 & 14 \\
\hline$K_{(9,1)} \ldots K_{(9,6)}$ & 20 & 16 & 11 & 20 & 20 & 13 \\
\hline$K_{(10,1)} \ldots K_{(10,6)}$ & 20 & 14 & 13 & 12 & 14 & 13 \\
\hline
\end{tabular}

У табл. 6 представлено остаточні розрахунки для визначення індексу креативності кожного члена команди освітнього проекту.

Оскільки суть методу управління трудовими ресурсами освітніх проектів з урахуванням їх креативності та ризиків полягає в тому, що один 3 членів команди ставиться в ситуацію вибору щодо інших членів коман(C) Ю. М. Кузьмінська, 2019 DOI: $10.24025 / 2306-4412.1 .2019 .165236$ ди проекту за тим чи іншим критерієм, то його було застосовано при оцінюванні ступеня довіри до кожного члена команди проекту.

Далі було визначено інтегральний показник оцінки «креативність-ризик» кожного члена команди освітнього проекту у сфері підвищення кваліфікації, який враховував як креативність, так і ризики. 
Таблиця 6 - Розрахунок індексу креативності кожного члена команди проекту

\begin{tabular}{|c|c|c|c|c|c|c|}
\hline $\begin{array}{c}\text { Індекс креа- } \\
\text { тивності }\end{array}$ & $\begin{array}{c}\text { Керівник } \\
\text { проекту }\end{array}$ & $\begin{array}{c}\text { Асистент } \\
\text { керівника } \\
\text { проекту }\end{array}$ & $\begin{array}{c}\text { Офіс- } \\
\text { менеджер }\end{array}$ & Бухгалтер & Юрист & $\begin{array}{c}\text { Менеджер зі } \\
\text { зв'язків 3 гро- } \\
\text { мадськістю та } \\
\text { реклами }\end{array}$ \\
\hline$K_{1}$ & 2,4 & 2,6 & 2,2 & 2 & 3 & 3,2 \\
\hline$K_{2}$ & 2,4 & 2,2 & 2,2 & 2,6 & 3,8 & 2 \\
\hline$K_{3}$ & 4 & 3,4 & 3 & 2,8 & 3 & 3 \\
\hline$K_{4}$ & 4 & 3,4 & 3 & 1,6 & 1,6 & 3,2 \\
\hline$K_{5}$ & 3,8 & 2,2 & 2,6 & 1,2 & 1,4 & 2,2 \\
\hline$K_{6}$ & 1,8 & 1,8 & 2 & 2 & 2,4 & 1,8 \\
\hline$K_{7}$ & 4 & 3,2 & 2,4 & 3,8 & 3,4 & 3,2 \\
\hline$K_{8}$ & 4 & 2,8 & 2,2 & 3 & 2,8 & 2,8 \\
\hline$K_{9}$ & 4 & 3,2 & 2,2 & 4 & 4 & 2,6 \\
\hline$K_{10}$ & 4 & 2,8 & 2,6 & 2,4 & 2,8 & 2,6 \\
\hline$K_{j}$ & 34,4 & 27,6 & 24,4 & 25,4 & 28,2 & 26,6 \\
\hline
\end{tabular}

Оскільки якісна співпраця членів команди проекту починається зі ставлення та довіри кожного члена команди проекту один до одного, то цей показник був названий автором «ступінь довіри» і позначався як $C R_{j}$.

Отже, в результаті проведеного дослідження ступінь довіри кожного члена команди освітнього проекту було визначено за формулою

$$
C R_{j}=K_{j}-R_{j} .
$$

У ході нашого дослідження для кожного члена команди проекту було визначено ступінь довіри за такою шкалою (у відповідній колонці табл. 7):

$3,0-10,38-$ низький;

10,38 - 17,76 - нижчий середнього;

17,76 - 25,14 - середній;

25,14 - 32,52 - вищий середнього;

32,52 - 39,9 - високий.

Остаточні розрахунки індексу $C R_{j}$ представлені у табл. 7.

Таблиця 7 - Розрахунок ступенів довіри

\begin{tabular}{|c|c|c|c|c|}
\hline $\begin{array}{c}\text { Члени команди } \\
\text { проекту }\end{array}$ & $K_{j}$ & $R_{j}$ & $C R_{j}$ & Ступінь довіри \\
\hline 1 & 34,40 & 0,90 & 33,50 & високий \\
\hline 2 & 27,60 & 1,39 & 26,21 & вищий середнього \\
\hline 3 & 24,40 & 1,35 & 23,05 & середній \\
\hline 4 & 25,40 & 1,15 & 24,25 & середній \\
\hline 5 & 28,20 & 1,10 & 27,10 & вищий середнього \\
\hline 6 & 26,60 & 1,03 & 25,57 & вищий середнього \\
\hline
\end{tabular}

Таким чином, ми отримали команду в основному з високими та середніми ступенями довіри, серед членів якої будуть обиратися ті, у кого індекс $C R_{j} \epsilon$ найбільшим, а отже, лише таких членів команди проекту необхідно було б призначати на паралельні або критичні роботи, або на роботи 3 високим пріоритетом.

У цьому випадку найбільші ступені довіри були у проектного менеджера $\left(C R_{l}=33,5\right)$, юриста $\left(C R_{5}=27,1\right)$, асистента керівника проекту $\left(C R_{2}=26,21\right)$ та менеджера зі зв'язків 3 громадськістю та реклами $\left(C R_{6}=25,57\right)$, тому такі роботи будуть розподілені саме серед цих членів команди освітнього проекту у сфері підвищення кваліфікації.

Достовірність отриманих результатів була підтверджена експериментально в ході реалізації цього проекту розробки та запуску програм підвищення кваліфікації за ваучерами в приватному закладі вищої освіти, під час якого індекс $C R_{j}$ кожного члена команди було контрольно перераховано. Отримані фактичні результати дуже близько збіглися 3 плановими: $C R_{1}=34,15 ; C R_{2}=28,38 ; C R_{3}=30,40$; $C R_{4}=25,93 ; C R_{5}=30,2 ; C R_{6}=28,16$. 
Висновки. Такий метод управління трудовими ресурсами дасть можливість попередити або хоча $б$ якось застрахуватися від ризиків, пов'язаних з членами команди освітнього проекту у сфері підвищення кваліфікації та їх високою креативністю. За допомогою представленої методики оцінювання вже на етапі планування проекту можна буде врахувати майбутні ризики та креативність. А отже, проектний менеджер зможе розставляти по критичних задачах креативних членів команди проекту таким чином, щоб проект був максимально успішним.

\section{Список літератури}

1. Проект положення про післядипломну освіту у сфері вищої освіти України. URL: old.mon.gov.ua/img/zstored/files/Проект $\% 20$ Положення\%20про\%20ПДО.doc

2. Білощицький А. О. Методологія проектновекторного управління освітніми середовищами: автореф. дис. ... д-ра техн. наук: спец. 05.13.22 «Управління проектами та програмами»; МОНМС України, Київ. нац. ун-т буд-ва і архітектури. Київ, 2012. 35 с.

3. Рулікова Н. С. Управління портфелем інноваційних проектів вищих навчальних закладів: автореф. дис. ... канд. техн. наук: спец. 05.13.22; Нац. ун-т кораблебудування ім. адмірала Макарова. Миколаїв, 2009. 20 с.

4. Коляда О. П. Проектно-ориентированная формализация стратегического компонента функциональной деятельности высшего учебного заведения. Управління проектами та розвиток виробництва: зб. наук. праць. 2008. № 3 (27). С. 81-87.

5. Рач В. А., Борзенко-Мірошніченко А. Ю. Проектно-орієнтовані моделі управління та оцінки діяльності вищих навчальних закладів. Управління проектами та розвиток виробництва: зб. наук. праць. 2009. № 1 (29). C. 81-89.

6. Кузьмінська Ю. М. Метод управління трудовими ресурсами освітніх проектів. Управління проектами: інноваиії, нелінійність, синергетика: матеріали V міжнар. наук.-практ. конф. магістрів, аспірантів та науковців. Одеса: ОДАБА, 2014. Т. 2. C. $122-125$.

7. Кузьмінська Ю. М. Когнітивна модель взаємовпливів ризиків проектів в сфері післядипломної освіти. Управління проектами у розвитку суспільства: тези доп. XII міжнар. конф. Київ: КНУБА, 2015. С. 144-146.

8. Кузьмінська Ю. М. Концептуальна модель управління командами освітніх проектів у сфері підвищення кваліфікації. Управління проектами: стан та перспективи: матеріали XIV Міжнар. наук.-практ. конф. Миколаїв: НУК, 2018.

9. Лепський В. В., Кузьмінська Ю. М. Застосування методу перехресної соціометричної оцінки до визначення креативності команди проекту. Вісник НТУ «ХПI»: зб. наук. праць. Серія: Стратегічне управління, управління портфелями, програмами та проектами. Харків: НТУ «ХПІ», 2015. № 2 (1111). C. 172-177.

10.Ткаченко Л. Г. Ваучери на навчання осіб віком старше 45 років як інструмент активної політики ринку праці. Демографія та соиіальна економіка. 2015. № 2 (24). C. 41-52.

11.Офіційний веб-сайт Держстату України. URL: http://www.ukrstat.gov.ua/operativ/opera tiv2017/rp/eans/eans_u/arch_znsmv_u.htm

12.Про зайнятість населення: Закон України. URL: https://zakon2.rada.gov.ua/laws/show/ 5067-17

13.Про затвердження Порядку видачі ваучерів для підтримання конкуренто-спроможності осіб на ринку праці: постанова КМУ № 207 від 20.03.2013 p. URL: https://zakon2.rada.gov.ua/laws/show/2072013-\%D0\%BF\#n13

14.Про затвердження Переліку професій, спеціальностей, напрямів підготовки та підвищення кваліфікації, для навчання за якими може бути виданий ваучер: наказ Мінсоцполітики № 661 від 25.06.2015 р. зі змінами та доповненнями. URL: https:// zakon2.rada.gov.ua/laws/show/ z0817-15

15.Кузьмінська Ю. М. Кадрові ризики в проектах післядипломної освіти. Стан та перспективи розвитку сочіально-економічних систем в епоху економіки знань: матеріали III міжнар. наук.-практ. конф. студентів, аспірантів та молодих вчених. Східноукр. нац. ун-т ім. В. Даля. Луганськ: Вид-во СНУ ім. В. Даля, 2014. С. 77-80.

\section{References}

1. Draft regulations on postgraduate education in higher education of Ukraine. URL: 
old.mon.gov.ua/img/zstored/files/Проект\%20

Положення\%20про\%20ПДО.doc

2. Biloshchitsky, A. O. (2012). Methodology of the project and vector management by educational environments: author's abstract for Dr.Tech.Sc.: 05.13.22 "Project and program management"; MONMS of Ukraine, Kyiv National University of Construction and Architecture. Kyiv, 35 p. [in Ukrainian].

3. Rulikova, H. S. (2009). Portfolio management of innovative projects of higher educational establishments: author's abstract for Ph.D.: 05.13.22; Admiral Makarov National University of Shipbuilding. Mykolaiv, 20 p. [in Ukrainian].

4. Koliada, O. P. (2008). Project-oriented formalization of strategic component of functional activity of a higher educational institution. Upravlinnya proektamy ta rozvytok vyrobnytstva: coll. of sci. works, No. 3 (27), pp. 8187 [in Russian].

5. Rach, V. A., Borzenko-Miroshnichenko, A. Yu. (2009). Project-oriented models of management and evaluation of the activities of higher educational institutions. Upravlinnya proektamy ta rozvytok vyrobnytstva: coll. of sci. works, No. 1 (29), pp. 81-89 [in Ukrainian].

6. Kuzminska, Yu. M. (2014). Method of management by educational projects labor forces. Upravlinnya proektamy: innovatsiyi, neliniynist, synergetyka: materials of the fifth Internat. conf. of masters, postgraduates and scientists. Odesa: ODABA, Vol.1, pp. 122-125 [in Ukrainian].

7. Kuzminska, Yu. M. (2015). Cognitive model of mutual influence of risks of projects in the field of postgraduate education. Upravlinnya proektamy u rozvytku suspilstva: abstracts of the twelfth Internat. conf. Kyiv: KNUBA, pp.144-146 [in Ukrainian].

8. Kuzminska, Yu. M. (2018). Conceptual model of educational project team management in the field of further training. Upravlinnya proektamy: stan ta perspektyvy: materials of the XIV Internat. sci.-pract. conf. Mykolayiv: NUK [in Ukrainian].

9. Lepsky, V. V, Kuzminska, Yu. M. (2015). Application of the cross-sociometric evaluation method in the determination of project team creativity. Visnyk NTU "KhPI": coll. of sci. works. Seriya: Strategichne upravlinnya, upravlinnya portfelyamy, programamy ta proektamy. Kharkiv: NTU "KhPI", No. 2 (1111), pp. 172-177 [in Ukrainian].

10.Tkachenko, L. H. (2015). Vouchers for the training of persons over 45 years of age as an active labor market policy tool. Demographiya ta sotsialna ekonomika, No. 2 (24), pp. 41-52 [in Ukrainian].

11. State Statistics Service in Ukraine. URL: http://www.ukrstat.gov.ua/operativ/operativ20 17/rp/eans/eans_u/arch_znsmv_u.htm

12.Law of Ukraine "On employment of the population". URL: https://zakon2.rada.gov.ua/ laws/show/5067-17

13.CMU Resolution "On approval of the Procedure for issuing vouchers for maintaining the competitiveness of individuals in the labor market" No. 207 dated March 20, 2013. URL: https://zakon2.rada.gov.ua/laws/show/2072013-\%D0\%BF\#n13

14. Order of the Ministry of Economic Affairs and Finance "On approval of the List of professions, specialties, directions of training and advanced training, for which training may be issued voucher" No. 661 dated 2015.06.25 with amendments and additions. URL: https://zakon2.rada.gov.ua/laws/show/z0817-15

15.Kuzminska, Yu. M. (2014). Personnel risks in postgraduate education projects. Stan ta perspektyvy rozvytku sotsialno-ekonomichnyh system $v$ epohu ekonomiky znan: materials of the Third Internat. sci.-pract. conf. of students, postgraduates and young scientists. V. Dahl Eastern Ukrainian National University. Luhansk: vyd-vo SNU im. V. Dahlya, pp. 77-80 [in Ukrainian]. 
Yu. M. Kuzminska, Director of the Higher School of Management e-mail: jkuzminskaya@gmail.com

PJSC «Interregional Academy of Personnel Management»

Frometivska str., 2, Kyiv, 03039, Ukraine

\section{PRACTICAL APPLICATION OF MODELS AND METHODS OF MANAGEMENT BY CREATIVITY AND RISKS OF EDUCATIONAL PROJECT TEAMS IN THE FIELD OF FURTHER TRAINING}

Modern life requires rapid and continuous development: professional knowledge, gained by a person, becomes outdated in several years and needs to be updated. In professional activities, there is always request for mobility and ability to change. The unevenness of staff training, overproduction of personnel in one profile harms other professions, actualizing the need for lifelong learning. Therefore, in the management by educational projects in the field of further training, which is a component of lifelong learning and a springboard for the growth of modern staff, project management works better.

Typically, a team of educational project consists of creative individuals selected from among the internal staff of educational institution. The management by such teams involves certain personnel risks, which may further undermine the successful completion of an educational project. The work with teams, the members of which have high creative potential, requires additional and effective tools and methods of management.

The article is devoted to aspects of practical application of author's models and methods of managing the creativity and risks of educational project teams in the field of further training. The author has made an assessment of the members' creativity using the sociometric cross-evaluation and the expert methods. The assessment has been based on an example of educational project for the development and launch of qualification improvement programs with vouchers in a private institution of higher education. This helped to identify personnel risks which influence the project results the most. The article shows how using the method of labor resources management in educational projects, taking into account creativity and risks, and the method of cross-evaluation, it is possible to determine the criteria of trust to each member of the project team for further planning the project by a human resources manager on the critical path of an educational project.

Keywords: educational project, sphere of professional development, project team, management, creativity, risks, degree of trust. 